\title{
RELEVANCE OF ISLAMIC EDUCATION IN THE FORMATION OF STUDENT CHARACTER
}

\author{
Sita Novia Muyassaroh, Amila Noor Khikmah, Shofia Isnaini, Paulina Anisatin Nabila \\ Faculty of Tarbiyah, Institut Agama Islam Negeri Kudus \\ Jl. Gondangmanis, Kudus, Central Java, Indonesia. 59322 \\ E-mail: shofiaisnaini8@gmail.com
}

\begin{abstract}
Character education is essentially a moral education that is expected to form a better and more responsible human person. This character education teaches how to think and behave well that help individuals to live and work together as a family, community and state, as well as helping them to make responsible decisions. In other words, this character education teaches how to educate children to think smartly, to have a healthy character and naturally to activate the child's brain naturally. Character education refers to religious education entitled Akhlaqul Karimah, which aims to encourage the habits and behavior of students. In terms of the religion of Islam to build human nature we need to follow in the footsteps of the Prophet Muhammad as role models of the people. He has a character that must be emulated.
\end{abstract}

Keywords: character education, Islamic religious education, students

\begin{abstract}
Abstrak: Pendidikan karakter hakikatnya adalah pendidikan akhlak yang diinginkan untuk membentuk kepribadian manusia yang menjadi lebih baik dan bertanggung jawab. Pendidikan karakter ini mengajarkan cara berfikir dan berperilaku baik yang membantu seseorang agar hidup dan bekerja sama sebagai keluarga, masyarakat dan bernegara, juga dapat membantu dalam mengambil keputusan yang dapat dipertanggung jawabkan. Dengan kata lain, pendidikan karakter ini mengajarkan cara mendidik anak berpikir cerdas, berkarakter sehat dan tentunya mengaktivitasi otak anak secara alami. Pendidikan karakter mengarah kepada pendidikan agama yang berujuk pada Akhlaqul Karimah, yang bertujuan untuk mendorong kebiasaan dan perilaku peserta didik. Dalam segi agama Islam untuk membangun watak manusia kita perlu mengikuti jejak Nabi Muhammad Saw sgai panutan umat. Beliau memiliki karakter yang harus diteladani.
\end{abstract}

Kata Kunci: pendidikan agama Islam, pendidikan karakter, peserta didik

\section{Introduction}

Education in Indonesia is actually less concerned towards character building of the young generation today. Through a series of efforts to improve academic and non-academic achievements, the excellence of the younger generation can be arranged. This can be a major factor causing graduates who do not yet reflect the character expected by national goals. Therefore, educational institutions should be balanced in determining the obligations in improving the achievement of quality, and responsible for the formation of good character. Character allows one to achieve progress and continuity. Character education requires high discipline because in character formation it must go through a process and not be instant. In such a good view, each individual will produce people who have character, piety and have integrity as self-actualization. In the success of character education that is applied, it is able to be the main foundation in order to succeed the existing educational goals.

\section{A. Definition of Islamic Education}

Religious education is a subject that must be included in the curriculum of every formal education institution in Indonesia. Because religious life is a life that can be realized and has been organized (Thoha et al., 1999). By studying religious education, everyone can live an Islamic pattern. Education comes from the Greek "Peadagogie", which means learning delivered to someone. Then translated into English "Education" which means development. In Arabic, there are terms for education, one of which is al-tarbiyah which means to educate and $a$ l-ta'dib which means to have the aim of perfecting one's character (Nizar, 2001). From this explanation can be taken the understanding that Islamic education is a lesson taught by a teacher to students who discuss lessons that are of Islamic value. 


\section{B. Definition of Character Education}

Education is an attempt by someone to change behavior and training to achieve a higher understanding of something. Whereas character is a depiction of behavior carried out by individuals by prioritizing character values. Character education is an effort of educators to understand something in students that serves to instill good values and actions towards God, self, and the surrounding environment. Educational development can be started from oneself through the family, community, and school environment, but in reality schools are considered more responsible for improving the character of students.

According to Ki Hadjar Dewantara, character is attitude. Someone will become a human who has a good personality if he has character. Education will be carried out well if students emphasize good character rather than bad character. Therefore, a successful education will create students who have noble character, not only intelligent but not yet optimal in terms of moral character (Wibowo \& Purnama, 2013). Whereas Ratna Megawati believes that learning aims to teach children to be able to make good decisions for themselves and around and then do it in life, so that it has a positive impact on the environment (Kesuma, 2011). Therefore, character education in an Islamic perspective is the result of the process of applying the shari'ah aqidah, where aqidah and shari'ah are pillars of character education in Islam (Syifa, 2014).

\section{The Importance of Character Building}

Prophet Muhammad SAW as uswatun khasanah who gave an example of attitude and exemplary about how to build a behavior, so that Michael H. Hart put the Prophet Muhammad as an influential human throughout human history, because he changed society into orderly and civilized. All was done by the Prophet Muhammad to build good and moral nation. Building character becomes a strong and distinctive responsibility. All that must start from the passion, vision, and example exemplified in the individual. So all life must move in an integrated manner in building character starting from the family, educational institutions and the social environment of the community (Saleh, 2012).

Character development is done to build the character of an individual to be much better, of course not only individuals but also the environment can also influence. Some characters such as honesty, discipline, and cleanliness (Muslich, 2011). It is related to the formation of character, to be able to be ethical, moral, polite and interact well with the community. As Samsuddin explained that character building must be included in the school curriculum (Hambali, 2012). Thomas Liekona (Barnawi \& Arifin, 2013), stated about the ten signs that are now happening, i.e:

a. Existence of violence among adolescents caused by an environment that is not supportive.

b. Use of non-standard language and words that are triggered by communication patterns with short message service (SMS)

c. Influence of friendship

d. Increased self-destructive behavior, such as using drugs.

e. Decreased work ethic

f. Culture of lies/dishonesty

Based on psychologist, Kohlberg (1992) and basic education expert, Marlene Lockheed (1990), there are four stages of character education that need to be done, i.e (Majid \& Andayani, 2011):

a. Habituation stage is the beginning of character formation.

b. Reasoning phase of student behavior.

c. Application stage of students in daily activities.

d. Meaning stage which leads to all attitudes and behaviors that have been carried out. As well as the benefits and bad things, these individuals will obtain that. Then the impact is sustainable on the relationship of education and student character.

\section{Relevance of Islamic education in character building}

Islamic personality is the behavior that exists in someone who is called the identity and characteristics of all behavior that is reflected from the source of Islamic religion. In Islam, a person is 
considered to have good character not only outwardly but also inwardly, or intentions that are heard by Allah SWT. In essence, the relation of Islamic education in the formation of student character can be seen from the example of the behavior of the prophet Muhammad SAW which reflects the commendable behavior that can be emulated by all humanity. In the hadith of the history of Muttafaq 'alaih, the following:

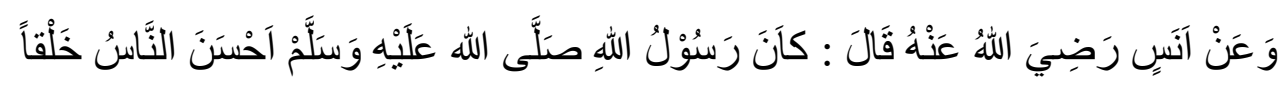

Meaning:

Anas RA said: "Rasulullah $S A W$ is the kindest person in bis character".

In the current development of education which is now formed into Curriculum 2013. Supported by the Minister of Education and Culture Regulation number 69 of 2013 which discusses the structure of the curriculum that discusses the learning of Islamic Religious Education as a mandatory reference in education in a religious environment and good character and character. Islamic Education aims to increase faith, devotion, and provide direction to practice students about the religion of Islam, so that it has a noble character in life (Muhaimin et al., 2008).

The concept of children's education according to intellectuals in the golden era needs to be examined as feedback and consideration. According to Al-Ghazali for example educating the child through three stages, namely memorizing, understanding, and believing. In this understanding, the author concludes that there is no need to restraint in educating the morals of children. Children will be able to understand well if done the right way (Aqib, 2012).

Imam Ghazali defines morals as traits embedded in the soul that give rise to various actions easily without the need for thought and consideration (Nata, 1995). While Ibn Sina said that all potential must be directed or formulated in each of their interests and talents. As with the development of talent, academic and ethical. In addition, Ibn Sina also argues that in the association of daily life, the purpose of an education is also one of the efforts to prepare to face social life, it is expected that they have sufficient provisions in character education. With this education, he hopes to have good character education in the social environment. In addition, when we can stimulate positive energy into the learning process, we can develop it in the actualization of self-development and talent development (Zuharini, 2004). The importance of fostering the character of the nation because of an ethical and moral crisis in the life of society, nation and state. To develop children's attitudes for the better learning system is needed Islamic Education. With Islamic education as a benchmark for children's morals, children will be better than their old personalities. Children will develop more according to Islamic rules. Therefore, teachers and parents do not need to worry.

\section{Conclusion}

Relevance of character education to Islamic Education in a character education that is formed from the application in the sharia process, can build character with noble character according to Islamic views. It can be likened to a building that stands firmly with the basic building materials in the form of morality and good morals. Islamic education learning has the aim of teaching the faith and understanding of religion in learning, as well as experiences about religion. In this case can increase the level of faith and piety for the Creator. Not only that, we can also receive reciprocity in life.

\section{References}

Aqib Z. 2012. Pendidikan Karakter di Sekolah. Bandung: CV. Yrama Widya.

Arifin, BS. 2019. Manajemen Pendidikan Karakter. Bandung: CV. Pustaka Setia.

Bamawi \& Arifin M. 2013. Strategi dan Kebijakan Pembelajaran Pendidikan Karakter. Yogyakarta: Ar-Ruzz.

Hambali. 2012. Jurnal El-Hikmah: Jurnal Pendidikan, Keagamaan, dan Sosial 12(1).

Kesuma D. 2011. Pendidikan Karakter. Bandung: PT. Remaja Rosdakarya.

Majid A \& Andayani D. 2011. Pendidikan Karakter Persepektif Islam. Bandung: PT. Remaja Rosdakarya.

Muhaimin et al. 2008. Paradigma Pendidikan Islam: Upaya Mengefektifkan PAI di Sekolah. Bandung: Remaja Rosdakarya. 
Muslich M. 2011. Pendidikan Karakter. Jakarta: PT Bumi Aksara.

Nata A. 1995. Akblak Tasawuf. Jakarta: Ruhama.

Nizar S. 2001. Pengantar Dasar-Dasar Pemikiran Pendidikan Islam. Jakarta: Gaya Media Pertama.

Peraturan Menteri Pendidikan Nasional Republik Indonesia Tahun 2006.

http://www.aidsindonesia.or.id/uploads/20130729141205.permendiknas_No22_Th_2006.pdf (16 Maret 2014).

Purnama S \& Wibowo A. 2013. Pendidikan Karakter di Perguruan Tinggi. Yogyakarta: Pustaka Pelajar.

Saleh AM. 2012. Membangun Karakter Dengan Hati Nurani. Jakarta: Penerbit Erlangga.

Syifa A. 2014. "Pendidikan Karakter dalam Perspektif Islam." Jurnal Pendidikan Universitas Garut 8(1).

Thoha C et al. 1999. Metodologi Pengajaran Agama. Yogyakarta: Pustaka Pelajar.

Zuhairini. 2004. Filsafat Pendidikan Islam. Jakarta: Bumi Aksara. 